\title{
Risk of violence and functional capacity of hospitalized elderly: a cross-sectional study
}

\author{
Risco de violência e capacidade funcional de idosos hospitalizados: estudo transversal \\ Riesgo de violencia y capacidad funcional de los ancianos hospitalizados: estudio transversal
}

How to cite this article:

Brandão BMLS, Santos RC, Araújo-Monteiro GKN, Carneiro AD, Medeiros FAL, Souto RQ. Risk of violence and functional capacity of hospitalized elderly: a cross-sectional study. Rev Esc Enferm USP. 2021;55:e20200528. DOI: https://doi.org/10.1590/1980-220X-REEUSP-2020-0528

\author{
Bárbara Maria Lopes da Silva \\ Brandão $^{1}$ \\ iD Renata Clemente dos Santos ${ }^{2}$ \\ D Gleicy Karine Nascimento de \\ Araújo-Monteiro $^{2}$

(D) Alan Dionizio Carneiro
(D) Fabíola de Araújo Leite Medeiros
(D) Rafaella Queiroga Souto \\ ${ }^{1}$ Universidade Federal de Pernambuco, Centro \\ de Ciências da Saúde, Recife, PE, Brazil. \\ ${ }^{2}$ Universidade Federal da Paraíba, Centro de \\ Ciências da Saúde, Programa de Pós-Graduação \\ em Enfermagem, João Pessoa, PB, Brazil. \\ ${ }^{3}$ Universidade Federal de Campina Grande, Centro \\ de Ciências Biológicas e da Saúde, Departamento \\ de Enfermagem. Campina Grande, PB, Brazil. \\ ${ }^{4}$ Universidade Estadual da Paraíba, Centro \\ de Ciências da Saúde, Departamento de \\ Enfermagem, Campina Grande, PB, Brazil.
}

\begin{abstract}
Objective: To analyze the risk of violence associated to functional capacity and sociodemographic characteristics of hospitalized elderly. Method: Quantitative, crosssectional, multicenter study conducted with elderly receiving care at university hospitals of the municipalities of João Pessoa and Campina Grande, in the state of Paraíba, Brazil. The scales Katz and Hwalek-Sengstock Elder Abuse Screening Test were applied. The data was analyzed through descriptive and inferential statistics using Chi-squared Pearson test, Spearman correlation test, and multiple logistic regression. Results: The participating elderly amounted to 323. The risk of violence was predominant among female elders aged 60 to 70 who are unable to read or write, live with someone, perform no labor activity, and whose income is higher than a minimum wage. Elders who were dependent for basic and instrumental activities presented a 2.11 score (Confidence Interval $=1.22-3.64 ; p=0.000)$ and $1.70(1.01-2.85 ; p=0.044)$ and a higher risk of violence. Conclusion: Elders who depended on other people to perform both complex and basic activities are the most exposed to situations of violence.
\end{abstract}

\section{DESCRIPTORS}

Aged; Violence; Activities of Daily Living; Geriatric Nursing; Health of the Elderly. 


\section{INTRODUCTION}

Violence against the elderly is defined by the World Health Organization as "any action, either isolated or repeated, or even the absence of due action, which causes suffering and distress in a relation in which there is expectation of confidence" ${ }^{\prime(1)}$. Considering that the aging process leads to physiological, functional, and social changes which favor vulnerability and interpersonal conflict, this process may also result in an increase of the prevalence of Violence against the Elderly ${ }^{(2)}$.

Given the increased prevalence of violence against the elderly, this phenomenon is verified to have advanced as an issue with little social visibility ${ }^{(2)}$. However, with the exponential increase of these cases, the outcomes were brought to the health environment and ratified as a public health problem. Concerning the prevalence of these cases worldwide, the results are observed to be heterogeneous, as shown by studies in Iran $(90.4 \%)^{(3)}$, Croatia $(21.4 \%)^{(4)}$, and Brazil (10\%) $)^{(5)}$.

The expansion of the phenomenon of violence against the elderly demonstrates different forms of aggression, including physical, psychological, sexual, and financial violence, abandonment, negligence, and self-inflicted violence; the first two are more predominant in the literature ${ }^{(6-7)}$. Also, some risk factors, such as geographic space, negative aging stereotypes, and sociocultural standards are emphasized ${ }^{(7)}$. In Brazil, the prevalence of these cases of aggression is related to females with low education and cognitive levels, lack of social support, and reduction of functional capacity ${ }^{(5)}$.

Functional capacity is characterized as the maintenance of the physical and mental abilities which are necessary for individual independence and autonomy, and may be measured through assessment instruments such as the Katz index, which assesses Basic Activities of Daily Living, referring to self-care activities; the Lawton test, which refers to Instrumental Activities of Daily Living, constituted of more complex actions, such as performing domestic tasks, cooking, and using means of transportation; and by Advanced Activities of Daily Living, which include independent leisure activities, social participation, work, and educational practices, depending, however, on personal motivation ${ }^{(8)}$. The above-mentioned instruments provide the determination of dependence or independence of elderly people for the execution of common daily life activities.

The degree of dependence is thus considered proportional to elderly dependence of care, frequently provided by relatives, which, by their turn, are also potential aggressors. For this reason, violence perpetrated by relatives represents most of the aggressions against the elderly and related factors are generally the reduction of functional capacity of this public and the consequent caregiver overload ${ }^{(9)}$.

Consequently, the decline of functional capacity may lead to damages to mobility and aggravation of clinical disorders which, added to a context of violence, may lead to the reduction of quality of life and an intensified risk of institutionalization, hospitalization, and mortality ${ }^{(10)}$.
With an increase in life expectancy and the growing number of chronic degenerative diseases, the demand for elderly hospitalization has also become frequent in hospitals. Therefore, this environment should be considered strategical for the identification of situations of violence. Nursing requires professionals with skills to detect situations of violence against the elderly ${ }^{(11)}$.

The role of nursing is thus emphasized, provided that these professionals have close and continuous contact with the patients, acting for the identification of risks and cases of violence by appropriately filling reports, providing care, follow-up, and monitoring cases of violence against the elderly. Nursing professionals are able to promote articulations and integrations among health, juridical, and social assistance services, which are crucial for the establishment of a social network for support and confrontation of this phenomenon ${ }^{(12)}$.

Regarding hospitalizations, although there are studies that relate the incidence of violence against the elderly and their respective hospitalizations, their number is still scarce. However, the permanence of elders at the health services provides an opportunity for the detection and intervention in the cycle of violence through critical care with an expanded outlook for qualified management of these occurrences.

Based on the above, this study has the following research question: do the performance of daily activities and sociodemographic factors influence the risk of violence among hospitalized elderly? Aiming at answering this question, the objective of this study was to analyze the risk of violence associated to functional capacity and sociodemographic characteristics of hospitalized elders.

\section{METHOD}

\section{Design of Study}

This is a quantitative, cross-sectional, multicenter study guided by the Strengthening the Reporting of Observational Studies in Epidemiology (STROBE) tool.

\section{Population}

Conducted with elderly receiving care at the University Hospital of the capital of the state of Paraíba (João Pessoa JP) and the second largest municipality of that state (Campina Grande-CG). The study's population comprised 1,259 elderly, who had been admitted to the sectors in the same collection period of the previous year.

\section{Selection Criteria}

The included individuals were aged 60 or more and were receiving care at the University Hospital Alcides Carneiro of Universidade Federal de Campina Grande and the University Hospital Lauro Wanderley of Universidade Federal da Paraíba.

The collection sectors of University Hospital Lauro Wanderley were Medical Clinic, Surgical Clinic, Infectious, Contagious and Parasitic Disease Unit, and Geriatric and Psychogeriatric Outpatient Unit. In the University Hospital Alcides Carneiro, the collection was performed in the 
surgical and pneumology wards and female and male medical clinic. These sectors were chosen for usually presenting a higher prevalence of elderly receiving care in relation to other hospital sectors.

The excluded elderly amounted to 46,23 due to being in a terminal stage, 12 due to presenting a severe communication difficulty, 10 for having clinical conditions that precluded participation, as in cases of hemodynamic instability, and 1 due to severe cognitive deficit. The assessment of these factors was performed by the researcher according to knowledge acquired during training for data collection or through information provided by the sector's professionals.

The sample was calculated through a finite population formula for epidemiological studies with expected frequency of $60 \%$, totaling 323 elders.

\section{Data Collection}

The data was collected from June 2019 to February 2020 with hospitalized elders who had been approached and invited to participate in the study. After accepting and signing the Informed Consent Form, a private area in the sector was chosen for the interview, guaranteeing the privacy of the interviewed. When the elder was bedridden, companions were politely asked to leave the area to provide better comfort and liberty for the elder to answer the questions on the risk of violence.

First, an instrument was applied for sample characterization and then Hwalek-Sengstock Elder Abuse Screening Test $(\mathrm{H}-\mathrm{S} / \mathrm{EAST})^{(13)}$; Katz index for basic activities ${ }^{(14)}$; Lawton and Brody scale for assessing instrumental activities $^{(15)}$; and a questionnaire adapted from the "Frailty in Brazilian Elderly" network for advanced activities ${ }^{(16)}$.

The sample characterization instrument contains the variables sex, age, marital status, reading and writing, living status, labor activity, and income. The H-S/EAST assesses the risk of violence through its score: one point is attributed to each affirmative answer, except for items 1, 6, 12, and 14 , in which the point is attributed to the negative answer. Scores higher than or equal to 3 indicates an increased risk of elderly suffering with violence ${ }^{(13)}$. The variable risk of violence was defined as the dependent variable of the study.

Basic activities were assessed through the Katz index, investigating elderly performance in lower complexity activities, such as moving, sphincter control, showering, dressing up, and eating. Elders who reported requiring help to perform at least one of the analyzed activities was classified as dependent ${ }^{(14)}$.

Concerning instrumental activities, the Lawton and Brody scale proposes an analysis of the capacity of the elders for performing intermediate complexity activities, in which the elder refers how much they need help to perform activities involving managing money, transportation, medication, use of telephone, and performing domestic tasks. Elders who referred requiring help for one of these activities was classified as dependent ${ }^{(15)}$.

Concerning advanced activities, the instrument assesses more complex activities, such as paying visits, driving automobiles, traveling, working, and attending university.
The elders were classified as more active or less active according to their participation in these activities. Those who performed four or more activities were classified as more active $^{(16)}$.

Three 4-hour training sessions were performed to prepare the team for the data collection phase. The collection team comprised 24 undergraduate students, 9 post-graduate students, and 5 professionals, all members of a study and research group on forensic nursing at Universidade Federal da Paraíba. A Google Docs spreadsheet was elaborated to avoid duplicity. It was fed with information (name, sector, age, medical record number) referring to elders which accepted research participation.

\section{Data Analysis and Treatment}

The data collection protocols were reviewed by two members qualified for this function and the data were tabulated into and analyzed with a statistical software through statistical (absolute and relative frequency) and inferential (Chi-squared Pearson Test, Spearman Correlation Test, Multiple Logistic Regression Model) analysis. The nonparametric test was chosen based on the result of the Kolmogorov-Smirnov normality test, in which the data presented a tendency to non-normality.

The criterion for entrance into the Logistic Regression Model was a p-value $<0.2$ in bivariate analysis; however, in the final model, a value of 0.05 or less was considered significant. For all tests a 5\% significance level was adopted ( $\mathrm{p}$-value $<0.05)$.

\section{Ethical Aspects}

This study is part of a project entitled "Instrumentalization of Forensic Nursing in face of hospitalized elderly care", approved by the Research Ethics Committee of the University Hospital Lauro Wanderley on opinion number 3.709.600/2019 and University Hospital Alcides Carneiro, opinion 3.594.339/2019, and which abided by resolution $466 / 12$ of the National Health Council.

\section{RESULTS}

The sample was composed of 323 elders, most of whom were female $(196 ; 60.7 \%)$, aged 60 to $70(170 ; 52.6 \%)$, able to read and write, living with someone $(288 ; 89.2 \%)$ and with an income of 1 to 2 minimum wages (259; 80.2\%).

In the association between risk of violence and the sociodemographic variables, as illustrated in Table 1 , there was a significance for sex $(p=0.004)$. The risk was predominant among elderly aged 60 to 70 (103; 60.9\%), with no partner $(104 ; 67.1 \%)$, unable to read and write (71; 68.9\%), living with someone $(181 ; 63.1 \%)$, performing no labor activity $(164 ; 65.1 \%)$, and whose income was above 1 minimum wage $(88 ; 65.2 \%)$.

There was an association between the risk of violence and the variables functional capacity of the elder, specifically among dependent elders, concerning basic daily activities $(\mathrm{p}<0.00)$, instrumental activities $(\mathrm{p}=0.001)$ and among 
Table 1 - Association between risk of violence and sociodemographic characteristics of the participants - Paraíba, Brazil, 2019-2020.

\begin{tabular}{lccc}
\hline \multirow{2}{*}{ Variables } & \multicolumn{2}{c}{ Risk of violence } & \\
\cline { 2 - 3 } & $\begin{array}{c}\text { With } \\
\mathbf{n}(\%)\end{array}$ & $\begin{array}{c}\text { Without } \\
\mathbf{n}(\%)\end{array}$ & p-value* \\
\hline Sex & $67(53.2)$ & $59(46.8)$ & \\
Male & $135(68.9)$ & $61(31.1)$ & 0.004 \\
Female & $103(60.9)$ & $66(39.1)$ & \\
\hline Age & $99(64.7)$ & $54(35.3)$ & 0.486 \\
60 to 70 & & & \\
Over 70 & $104(67.1)$ & $51(32.9)$ & 0.109 \\
\hline Marital status & $97(58.4)$ & $69(41.6)$ & \\
Without partner & & & \\
With partner & & & \\
\hline
\end{tabular}

Able to read and write

\begin{tabular}{lccc} 
Yes & $131(59.8)$ & $88(40.2)$ & 0.115 \\
No & $71(68.9)$ & $32(31.1)$ & \\
\hline Living status & & & \\
Lives alone & $21(60.0)$ & $14(40.0)$ & 0.723 \\
Lives with someone & $181(63.1)$ & $106(36.9)$ & \\
\hline
\end{tabular}

Labor activity

\begin{tabular}{llll} 
Yes & $38(54.3)$ & $32(45.7)$ & \\
No & $164(65.1)$ & $88(34.9)$ & 0.098 \\
\hline
\end{tabular}

Income

\begin{tabular}{lccc} 
Up to $1 \mathrm{MW}$ & $114(61.0)$ & $73(39.0)$ & \\
Over $1 \mathrm{MW}$ & $88(65.2)$ & $47(34.8)$ & 0.439 \\
\hline
\end{tabular}

Note: *Pearson Chi-squared test.; MW - Minimum wage; $(\mathrm{N}=323)$.

less active elders $(\mathrm{p}=0.015)$ for the execution of advanced activities, as shown in Table 2.

All functional capacity variables presenting $\mathrm{p}<0.2$ in the bivariate analysis were inserted into the logistic regression model, as exposed in Table 3. In the final model, the basic and instrumental daily life activities maintained significance, which enables the inference that elders who are dependent for basic and instrumental activities with, respectively, $2.11(\mathrm{CI}=1.22-3.64 ; \mathrm{p}=0.000)$ and $1.70(1.01-2.85$; $\mathrm{p}=0.044)$ have a higher possibility of presenting risk of violence when compared to those who are independent.

The area of the Receiver Operating Characteristics (ROC) curve for the logistic regression model concerning risk of violence was $0.63(\mathrm{p}<0.000)$, as observed in Figure 1 .

Table 4 shows that, in the analysis of correlation of the total score for risk of violence and functional capacity, all variables presented significance, indicating that the more dependent and less active the elder is, the higher is the risk of violence.
Table 2 - Distribution of the variables of functional capacity with risk of violence among elderly - Paraíba, Brazil, 2019-2020.

\begin{tabular}{lccc}
\hline \multirow{2}{*}{ Variables } & \multicolumn{2}{c}{ Risk of violence } & \\
\cline { 2 - 3 } & $\begin{array}{c}\text { With } \\
\mathbf{n}(\%)\end{array}$ & $\begin{array}{c}\text { Without } \\
\mathbf{n}(\%)\end{array}$ & p-value* \\
\hline Basic activities & & & \\
Independent & $110(54.7)$ & $91(45.3)$ & 0.000 \\
Dependent & $92(76.0)$ & $29(24.0)$ & \\
\hline Instrumental activities & & & \\
Independent & $56(50.0)$ & $56(50.0)$ & 0.001 \\
Dependent & $146(69.5)$ & $64(30.5)$ & \\
\hline Advanced activities & & & \\
More active & $123(57.7)$ & $90(42.3)$ & 0.015 \\
Less active & $70(72.2)$ & $27(27.8)$ & \\
\hline
\end{tabular}

Note: *Pearson Chi-squared test; $(\mathrm{N}=323)$.

Table 3 - Variables associated to risk of violence and functional capacity through multiple logistic regression - Paraíba, Brazil, 2019-2020.

\begin{tabular}{lccc}
\hline Variables & OR & $\mathrm{Cl}$ & p-value* \\
\hline Basic activities & & & \\
Independent & 1.00 & - & - \\
Dependent & 2.11 & $1.22-3.64$ & 0.000 \\
\hline Instrumental activities & & & \\
Independent & 1.00 & - & - \\
Dependent & 1.70 & $1.01-2.85$ & 0.044 \\
\hline
\end{tabular}

Note: $\mathrm{R}^{2}$ - 0.079; OR - Odds Ratio; $\mathrm{Cl}$ - Confidence interval; * Test significance.

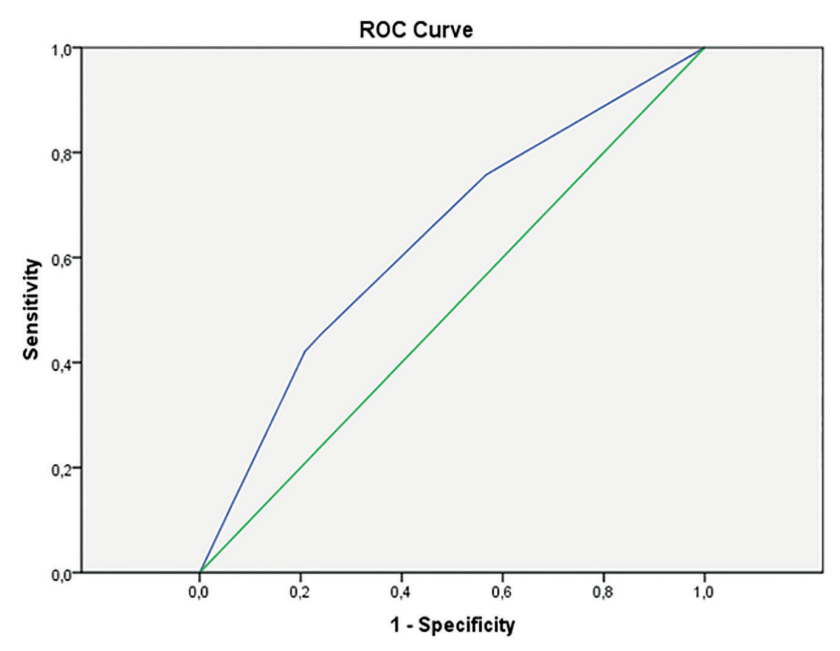

Diagonal segments are produced by ties.

Figure 1 - Receiver Operating Characteristics curve based on the logistic regression model of risk of violence - Paraíba, Brazil, 2019-2020.

\section{DISCUSSION}

A study developed in Spain reports the experience of implementing a suspect cases of violence detection plan among hospitalized elders through Comisión Contra la 
Table 4 - Correlation between the scores of risk of violence and functional capacity - Paraíba, Brazil, 2019-2020.

\begin{tabular}{lcc}
\hline & \multicolumn{2}{c}{ Risk of violence total score } \\
\cline { 2 - 3 } & Correlation coefficient & p-value* \\
\hline $\begin{array}{l}\text { Total score of basic } \\
\text { activities }\end{array}$ & 0.263 & 0.000 \\
$\begin{array}{l}\text { Total score of instrumental } \\
\text { activities }\end{array}$ & 0.283 & 0.000 \\
$\begin{array}{l}\text { Total score of advanced } \\
\text { activities }\end{array}$ & -0.138 & 0.015 \\
\hline
\end{tabular}

Note: *Spearman correlation test.

Violencia del Hospital Clinico San Carlos and the findings of its 3-year investigation concluded that this tool may be adopted in several health environments and that emergency is the most appropriate place for detection of this phenomenon. The victim profile was observed to be women with severe physical and cognitive disability ${ }^{(17)}$. This study's findings have shown that there was a significant association between risk of violence and being a female, reaffirming previous studies $^{(6,17-18)}$.

Although distinct, since violence against the elderly involves intergenerational relations and violence against women relates to gender issues, both aggressions are based on asymmetric power relations and may be associated. In this context, elderly women have become more vulnerable, given that culturally they are longer at home with a more restricted social circle and are frequently exposed to financial and emotional submission by family members. This subordination favors stressful situations and depressive symptoms, factors which influence the increase of violence ${ }^{(19)}$.

Concerning age group, younger elderly are emphasized to constitute a risk factor for violence; however, these are also the main reporters of violence ${ }^{(20-21)}$. Considering that in this period physical vigor and cognitive and functional capacity tend to be more well-preserved, these elders better express their autonomy, opposing and confronting aggressors, seeking for help and reporting abuses.

Paradoxically, violence is used by aggressors as a means of displaying power in which, through force, they try to subjugate these elders and neutralize tensions and fighting attitudes of the victims, which implies a higher risk of aggression. Differently from this study, research conducted in countries such as Iran, USA, and Brazil have approached, among their findings, violence against the elderly in communities, with cases of domestic violence, as well as reported aggression against the elderly. Although they analyze distinct populations, these studies have shown that advanced age may be considered a risk factor for violence due to the dependencies generated by comorbidities themselves, and functional and psychological vulnerabilities acquired with longevity, emphasizing that elderly frailty is considered a risk factor for violence, considering that fragile elders may be more susceptible to diverse forms of violence, mainly due to a lack of reaction capacity ${ }^{(3)}$.

Low education was shown to be a social determinant for potential risk of violence ${ }^{(22)}$. A study conducted in
South Korea has shown an interaction between gender and low educational levels, emphasizing gender role in situations of violence in which women took domestic and familial social roles, whereas men executed external activities conditioned to educational requirements ${ }^{(23)}$. These historical conditions directly influence the occurrence and the type of violence perpetrated against females ${ }^{(23)}$.

Also, the increased risk of violence against elders with lower education may be related not only to a higher permanence in the domestic environment, but also to difficulties of the victims to identify the forms of violence and the little awareness of their own rights and how to guarantee them so as to interrupt the cycle of violence, even though they recognize the need for health care to treat violence aggravations. This aspect corroborates the understanding that health services have an important role in the network of services which are targeted at fighting violence against the elderly.

Another relevant aspect of violence against the elderly refers to people who live in their family environment, given that, depending on who shares the house with the elder, different forms of violence may be practiced. According to a systematic review, living with other family members constituted a risk of negligence; living with the family of a married son/daughter or only with son/daughter contributed to financial violence; and living with a quarrelsome family configured a risk of psychological, physical, and economic violence and negligence ${ }^{(7)}$.

However, not having a partner is also a violence risk factor, mainly among widows. The frequency of widows among females demonstrates the effect of feminization and susceptibility to poverty and intellectual dependence. Therefore, there may be a predisposition to financial and patrimonial violence and negligence, according to recent investigations in India ${ }^{(6)}$.

Considering the wage of this study's elderly, higher than a minimum wage, as a risk of violence, it is possible to establish a causal relation with financial violence, in which the aggressor has the intention of appropriating the elder's goods and finances ${ }^{(21)}$. Another perspective which should be emphasized refers to the absence of labor activities as a risk factor for violence, since maintenance of work is associated to physical and cognitive capacity for performing labor activities, preservation of autonomy, and economic independence. Taking into account that most elders' income comes from retirement pension, labor disability and frequent functional disability may impose a longer permanence in the domestic environment and social distancing ${ }^{(24)}$.

Functional dependence represents a risk factor for violence due to stress provoked by the degree of care required by the elder ${ }^{(23)}$. The fact that basic and instrumental daily activities increase by twice the risk of violence may be shown in different contexts of practice. In a study with community elders and their respective caregivers, high levels of overload were observed to occur with an 11-time increase in the probability of violence ${ }^{(9)}$.

In this context, caregivers, usually informal, are not qualified to provide transversal care to functional dependence 
and, in the absence of periodic follow-up by health professionals, there is a difficulty for identifying episodes of violence, given that the elderly do not usually report them due to fear of being left unassisted ${ }^{(25)}$. Also, imposing excessive tasks which are beyond the elders' physical capacities, is a tactic used by aggressors to diminish them.

Concerning long-stay institutions, a study conducted with nursing teams in a Norwegian institution has shown that $60.8 \%$ of its professionals had committed one or more episodes of abuse within a year, varying from psychological violence to negligence ${ }^{(26)}$. Since power relations are represented in these environments by caregiving professionals, violence may lead to verbal aggression, used to maintain order and control over the elderly. Nonetheless, these acts are justified by operational flaws, communication difficulties, and excessive activities, including negligence of tasks which are not recognized as an individual responsibility, possibly contrasting with the elders' perceptions ${ }^{(4)}$.

Regarding hospitals, the literature demonstrates that elders hospitalized for mistreatment had longer hospitalizations and higher economic and social protection costs ${ }^{(27)}$. Also, concerning the risk of violence in these establishments, physical violence is pointed out to be possibly due to excessive procedures, invasive treatment, and lesions due to falling ${ }^{(12)}$; negligent attitudes, by their turn, are equivalent to the discussion about professionals in long-stay institutions ${ }^{(4)}$. Considering that the elderly in this study were affected by functional decline, such situations of violence may exacerbate the impairment of this ability and lead to other negative outcomes.

Since functional dependence involves risk of violence, the results concerning advanced daily activities are similar. Less active elders, i.e., those who are less engaged in daily leisure and social participation activities, tend to have a higher susceptibility to violence. Although no studies which point out this association have been identified, it is possible to infer that these activities have the capacity of preventing cognitive decline and social isolation ${ }^{(16)}$, considered risk factors for violence ${ }^{(28)}$.

Hospitalization is one of the causes which contribute the most to functional disability in the elderly, given that the resolution of the reason for hospitalization may lead to a new problem for these individuals, since most elders do not recover the functionality they demonstrate before admission ${ }^{(29)}$.
The consequences of hospitalization tend to lead the elder to a reduction of various functions and consequent abandonment by their relatives and other types of violence ${ }^{(12)}$.

Based on the data analyzed in this study, it is possible to show how health professionals in hospital institutions, especially nursing professionals, must be apt to assess the evidences and risks of situations of violence against the elderly, knowing how to search for signs of violence in the clinical history of patients, their functional and cognitive capacities, and their social and family contexts. Aggravations that lead the elders to hospital services due to violence are also emphasized to be usually severe, with disproportionality between the findings of clinical anamnesis and contextual narrative of their causes, and these services thus acquire a strategic end deontic position for the interruption of the cycle of violence ${ }^{(30)}$.

Considering the interdisciplinary work in the hospital context, health professionals providing elderly care must be qualified to fight violence. Therefore, understanding factors associated to the risk of violence against the elderly and competences for assertive and efficient care may subsidize appropriate interventions, observing register and documentation completion and detailing and guaranteeing juridical and protection rights through a multidisciplinary social assistance network so as to protect victimized elderly, make aggressors responsible, and break with the cycle of violence.

A limitation of this study is the impossibility of using a technique of probabilistic sampling, as well as the lack of options of tracking instruments for all types of violence having a transcultural adaptation for the Brazilian context. However, this limitation does not compromise the quality of its findings and maintains the study's viability.

\section{CONCLUSION}

Functional capacity presented a significant relation with the risk of violence among hospitalized elders who are dependent for daily life and instrumental activities and less active for advanced activities. The elders who depended on relatives and health professionals to perform both complex and basic activities in the hospital environment were verified to be more exposed to situations of violence. These variables present a direct correlation, i.e., the development of one of them may increase the risk for the other situation, which, by its turn, reinforces the former, leading to a cycle of losses.

\section{RESUMO}

Objetivo: Analisar o risco de violência associado à capacidade funcional e características sociodemográficas de idosos hospitalizados. Método: Estudo quantitativo, transversal e multicêntrico, desenvolvido com idosos atendidos em hospitais universitários dos municípios de João Pessoa e Campina Grande, Paraíba, Brasil. Foram aplicadas as escalas de Katz e a Hwalek-Sengstock Elder Abuse Screening Test. Os dados foram analisados por estatística descritiva e inferencial utilizando testes qui-quadrado de Pearson, correlação de Spearman e regressão logística múltipla. Resultados: Participaram 323 idosos. O risco de violência foi predominante entre idosas, com idade entre 60 e 70 anos, que não sabem ler e escrever, moram com alguém, não exercem atividade laboral e possuem renda acima de um salário mínimo. Os idosos dependentes para as atividades básicas e instrumentais apresentam escore de 2,11 (Intervalo de Confiança = 1,22-3,64; $\mathrm{p}=0,000)$ e $1,70(1,01-2,85 ; \mathrm{p}=0,044)$ e maior risco de violência. Conclusão: Os idosos que dependem de terceiros para realizar tanto as atividades mais complexas quanto as mais básicas são aqueles que estão mais expostos às situações de violência.

\section{DESCRITORES}

Idoso; Violência; Atividades Cotidianas; Enfermagem Geriátrica; Saúde do Idoso. 
RESUMEN

Objetivo: Analizar el riesgo de violencia asociado a la capacidad funcional y a las características sociodemográficas de los ancianos hospitalizados. Método: Estudio cuantitativo, transversal y multicéntrico, desarrollado con pacientes ancianos atendidos en hospitales universitarios de los municipios de João Pessoa y Campina Grande, en el estado de Paraíba, en Brasil. Se aplicaron la escala de Katz y el Hwalek-Sengstock Elder Abuse Screening Test. Los datos se analizaron mediante estadística descriptiva e inferencial utilizando las pruebas de chi-cuadrado de Pearson, de correlación de Spearman y la regresión logística múltiple. Resultados: Participaron 323 ancianos. E1 riesgo de violencia fue predominante entre las ancianas con una edad de entre 60 y 70 años, que no saben leer ni escribir, viven con alguien, no ejercen ninguna actividad laboral y tienen una renta superior a un salario mínimo. Los ancianos dependientes para las actividades básicas e instrumentales presentaron una puntuación de 2,11 (Intervalo de Confianza = 1,22-3,64; p = 0,000) y 1,70 (1,01$2,85 ; \mathrm{p}=0,044)$ y un mayor riesgo de violencia. Conclusión: Los ancianos que dependen de otros para realizar tanto las actividades más complejas como las más básicas son los que están más expuestos a situaciones de violencia.

\section{DESCRIPTORES}

Anciano; Violencia; Actividades Cotidianas; Enfermería Geriátrica; Salud del Anciano.

\section{REFERENCES}

1. Silva GCN, Almeida VL, Brito TRP, Godinho MLC, Nogueira DA, Chini LT. Violência contra idosos: uma análise documental. Aquichan. 2018;18(4):449-60. http://dx.doi.org/10.5294/aqui.2018.18.4.7

2. World Health Organization. Missing voices: views of older persons on elder abuse [Internet]. Geneva: WHO; 2002 [cited 2020 June 02]. Available from: https://apps.who.int/iris/handle/10665/67371

3. Piri N, Tanjani PT, Khodkarim S, Etemad K. Domestic elder abuse and associated factors in elderly women in Tehran, Iran. Epidemiol Health. 2018;40:e2018055. http://dx.doi.org/10.4178/epih.e2018055

4. Neuberg M, Meštrović T, Ribić R, Šubarić M, Canjuga I, Kozina G. Contrasting vantage points between caregivers and residents on the perception of elder abuse and neglect during long-term care. Psychiatr Danub. 2019;31 Suppl 3:345-53.

5. Machado BP, Araújo IMB, Figueiredo MCB. Forensic nursing practice. What do the students know anyway? Forensic Sci Int. 2020;2: 138-43. http://dx.doi.org/10.1016/j.fsisyn.2020.04.003

6. Sudan A, Shahi P, Julka D. Prevalence of abuse in elders with psychiatric morbidity and its sociodemographic association. Cureus. 2020;12(4):e7906. http://dx.doi.org/10.7759/cureus.7906

7. Santos MAB dos, Moreira RS, Faccio PF, Gomes GC, Silva VL. Factors associated with elder abuse: a systematic review of the literature. Ciênc Saúde Coletiva. 2020;25(6):2153-75. http://dx.doi.org/10.1590/1413-81232020256.25112018

8. Aguiar BM, Silva PO, Vieira MA, Costa FM, Carneiro JA. Evaluation of functional disability and associated factors in the elderly. Rev Bras Geriatr Gerontol. 2019;22(2):e180163. http://dx.doi.org/10.1590/1981-22562019022.180163

9. Lino VTS, Rodrigues NCP, Lima IS, Athie S, Souza ER. Prevalência e fatores associados ao abuso de cuidadores contra idosos dependentes: a face oculta da violência familiar. Ciênc Saúde Coletiva. 2019;24(1):87-96. http://dx.doi.org/10.1590/1413-81232018241.34872016

10. Almakki ZE, Alshehri SZ, Wahab MAM. Knowledge and attitudes regarding elder abuse in the community, Eastern Province Saudi Arabia. BMC Geriatr. 2020;20:85. https://doi.org/10.1186/s12877-020-1416-4

11. Castro VC, Rissardo LK, Carreira L. Violence against the Brazilian elderlies: an analysis of hospitalizations. Rev Bras Enferm. 2018;71 Suppl 2:777-85. http://dx.doi.org/10.1590/0034-7167-2017-0139

12. Naderi Z, Gholamzadeh S, Zarshenas L, Ebadi A. Hospitalized elder abuse in Iran: a qualitative study. BMC Geriatr. 2019;19:307. https:// doi.org/10.1186/s12877-019-1331-8

13. Reichenheim ME, Paixão Jr CM, Moraes CL. Adaptação transcultural para o português (Brasil) do instrumento Hwalek-Sengstock Elder Abuse Screening Test (HS/EAST) utilizado para identificar risco de violência contra o idoso. Cad Saúde Pública. 2008;24:1801-13. http:// dx.doi.org/10.1590/S0102-311X2008000800009

14. Katz S, Akpom CA. A Measure of primary sociobiological functions. Int J Health Serv. 1976;6(3):493-508. http://dx.doi.org//10.2190/ uurl-2ryu-wryd-ey3k

15. Lawton MP, Brody EM. Assessment of older people: self-maintaining and Instrumental Activities of Daily Living. Gerontologist. 1969;9(3):179-86. http://dx.doi.org/10.1093/geront/9.3_Part_1.179

16. Oliveira EM, Silva HS, Lopes A, Cachioni M, Falcão DVS, Batistoni SST, et al. Atividades Avançadas de Vida Diária (AAVD) e desempenho cognitivo entre idosos. Psico USF. 2015;20(1):109-20. http://dx.doi.org/10.1590/1413-82712015200110

17. Del Nogal ML, Férnandez C, Serrano P, Santiago A, Villavicencio P, Martin T. Detección y seguimiento de malos tratos en personas mayores en un hospital terciario: experiencia de 3 años. Rev Esp Geriatr Gerontol. 2018;53(1):15-8. https://doi.org/10.1016/j.regg.2017.02.003

18. Agunbiade OM. Explanations around physical abuse, neglect and preventive strategies among older Yoruba people (60p) in urban Ibadan Southwest Nigeria: a qualitative study. Heliyon. 2019;5:e02888:1-13. http://dx.doi.org/10.1016/j.heliyon.2019.e02888

19. Machado DR, Kimura M, Duarte YAO, Lebrão ML. Violência contra idosos e qualidade de vida relacionada à saúde: estudo populacional no município de São Paulo, Brasil. Ciênc Saúde Coletiva. 2020;25(3):1119-28. http://dx.doi.org/10.1590/1413-81232020253.19232018

20. Rodrigues RAP, Santos AMR, Pontes MLF, Monteiro EA, Fhon JRS, Bolina AF, et al. Report of multiple abuse against older adults in three Brazilian cities. PLoS One. 2019;14(2):e0211806. http://dx.doi.org/10.1371/journal. pone.0211806

21. Santos AMRD, Nolêto RDDS, Rodrigues RAP, Andrade EMLR, Bonfim EG, Rodrigues TS. Violência econômico-financeira e patrimonial contra o idoso: estudo documental. Rev Esc Enferm USP. 2019;53:e190182. https://doi.org/10.1590/s1980-220x2017043803417

22. Amaral AKFJ, Moreira MASP, Coler MA, Saler MSCF, Mendes FRP, Silva AO. Violência e maus tratos contra a pessoa idosa: representações sociais de jovens, adultos e idosos. Rev Enferm UERJ. 2018;26:e31645. http://dx.doi.org/10.12957/reuerj.2018.31645 
23. Jeon GS, Cho SI, Choi K, Jang KS. Gender differences in the prevalence and correlates of elder abuse in a community-dwelling older population in Korea. Int J Environ Res Public Health. 2019;16(1):100. http://dx.doi.org/10.3390/ijerph16010100

24. Carmona-Torres JM, Carvalhal-Silva RM, Vieira-Mendes MH, Recio-Andradre B, Goergen T, Rodríguez-Borrego MA. Elder abuse within the family environment in the Azores Islands. Rev Latino Am Enfermagem. 2017;25e2932. http://dx.doi.org/10.1590/1518-8345.1871.2932

25. Silva CFS, Dias CMSB. Violência contra idosos na família: motivações, sentimentos e necessidades do agressor. Psicol Ciênc Prof. 2016;36(3):637-52. http://dx.doi.org/10.1590/1982-3703001462014

26. Botngård A, Eide AH, Mosqueda L, Malmeda W. Elder abuse in Norwegian nursing homes: a cross-sectional exploratory study. BMC Health Serv Res. 2020;20:9. http://dx.doi.org/10.1186/s12913-019-4861-z

27. Baker PRA, Francis DP, Hairi NH, Othman S, Choo WY. Interventions for preventing abuse in the elderly. Cochrane Database Syst Rev. 2016;(8):CD010321. http://dx.doi.org/10.1002/14651858.CD010321.pub2

28. Sathya T, Premkumar R. Association of functional limitations and disability with elder abuse in India: a cross sectional study. BMC Geriatr. 2020;20:220. http://dx.doi.org/10.1186/s12877-020-01619-3

29. Velilla NM, Herrero AC, Ferraresi FZ. Effect of exercise intervention on functional decline in very elderly patients during acute hospitalization: a randomized clinical trial. JAMA. 2019;179(1):28-36. http://dx.doi.org/10.1001/jamainternmed.2018.4869

30. Nicolau IF, Prado JA, Gonçalves LDPP, Pacheco RF, Souza SD. Considerações acerca da atuação da psicologia frente a situações de violência em um hospital de urgência e emergência. Rev Med Minas Gerais. 2018;28 Supl. 5:S280512. http://dx.doi.org/105935/22383182.20180124 